Jürgen Schneider-Schaulies,
Anneliese Schimpl and
Eberhard Wecker

Institut für Virologie und Immunbiologie, Würzburg

\section{Kinetics of cellular oncogene expression in mouse lymphocytes II. Regulation of c-fos and c-myc gene expression*}

Newly isolated lymphocytes from mouse spleens express the c-fos oncogene even in the absence of mitogen with maximal mRNA levels 60 min post preparation of single cell suspension, whereas c-myc mRNA levels increase only after mitogenic stimulation with maximal mRNA levels $6 \mathrm{~h}$ post stimulation.

The half-lives of $c$-fos mRNA are generally very short; they increase from $14 \mathrm{~min}$ (after $30 \mathrm{~min}$ of culture) to $70 \mathrm{~min}$ (after $2 \mathrm{~h}$ of culture). The half-lives of c-myc mRNA decrease from 50 min (at 2 and 6 h post stimulation with concanavalin A) to $12 \mathrm{~min}$ (at $48 \mathrm{~h}$ post stimulation).

The c-fos gene transcription is already turned on in time- 0 lymphocytes $10 \mathrm{~min}$ after disruption of the organ structure of the spleens and is down-regulated after $2 \mathrm{~h}$ and later. In nuclear run-on experiments with nonstimulated lymphocytes there is already significant transcription of the first exon of c-myc, but almost no elongation of the transcript to exon 2 and 3 . In concanavalin A-treated lymphocytes elongation is stimulated about 5-fold within $6 \mathrm{~h}$ and returns to background levels at $48 \mathrm{~h}$ post stimulation.

The nuclear run-on analyses of nonactivated lymphocytes showed a signal for RNA complementary to c-myc mRNA detected with a probe specific for the exon 1/intron 1 boundary of c-myc, which disappeared with increasing time of concanavalin A stimulation. This anti-sense transcription may play a role in regulating the elongation of $c-$ myc transcripts.

\section{Introduction}

It is by now well established that mRNA levels of several cellular oncogenes such as c-myc, c-fos and c-myb are increased in cell lines and normal cells during transition from $\mathrm{G}_{0}$ to S-phase [1-7]. High levels of $\mathrm{c}$-fos expression were also detected in differentiated macrophages $[6,8,9]$, but $c$-fos expression is neither sufficient nor obligatory for differentiation of monomyelocytes to macrophages [10]. The down-regulation of c-fos mRNA levels in 3T3, HL-60 and U937 cells was observed to be caused by transcriptional shutoff and a rapid degradation of the c-fos mRNA $[10,11]$. In normal mouse lymphocytes, c-myc expression is stimulated by various mitogens and growth factors $[1,12,13]$; however, the levels of $c-$ myc mRNA in mouse T lymphocytes depend on the type of mitogen used and the subpopulation of $T$ cells investigated [14]. The down-regulation of c-myc mRNA levels in lymphocytes and various cell lines is caused by post-transcriptional mechanisms influencing the stability of mRNA and treatment of cells with cycloheximide (CHI) leads to accumulation of $c$ myc mRNA [1, 2, 15-18]. We determined the half-lives of $c-$ fos and c-myc mRNA in normal mouse lymphocytes at various times after mitogenic stimulation and compared mRNA levels with those of precursor mRNA and with gene transcription rates.

[I 5915]

\footnotetext{
* This work was supported by SFB 165 of the Deutsche Forschungsgemeinschaft.
}

Correspondence: Eberhard Wecker, Institut für Virologie und Immunbiologie, Versbacher Str. 7, D-7800 Würzburg, FRG

Abbreviations: CHI: Cycloheximide Con A: Concanavalin A FCS: Fetal calf serum

\section{Materials and methods}

\subsection{Cell culture and determination of proliferative activity}

Newly preparated single cell suspensions of lymphocytes from mouse spleens were cultured in RPMI 1640 medium (Gibco, Grand Island, NY) supplemented with nonessential amino acids, 2-mercaptoethanol $\left(5 \times 10^{-5} \mathrm{M}\right)$, streptomycin $(100 \mu \mathrm{g} /$ $\mathrm{ml})$, penicillin $(100 \mathrm{U} / \mathrm{ml})$ and $5 \%$ heat-inactivated fetal calf serum (FCS). T cells were polyclonally activated with concanavalin A (Con A; $2.5 \mu \mathrm{g} / \mathrm{ml})$. To determine the rate of DNA synthesis $5 \times 10^{4}$ lymphocytes were pulsed for $16 \mathrm{~h}$ with $5 \mu \mathrm{Ci}=185 \mathrm{kBq}\left[{ }^{3} \mathrm{H}\right]$ thymidine $(2 \mathrm{Ci} / \mathrm{mmol})$. Some of the cultures were treated for $1 \mathrm{~h}$ with $10 \mu \mathrm{g} / \mathrm{ml}$ CHI (Sigma, St. Louis, MO) after appropriate times of stimulation. RNA synthesis was blocked by $5 \mu \mathrm{g} / \mathrm{ml}$ actinomycin $\mathrm{D}$ (Act D).

\subsection{Preparation of RNA and analysis}

Lymphocytes were pelleted by 5 min centrifugation, dissolved in guanidinium rhodamid buffer and total cellular RNA was pelleted through a caesium chloride cushion as described [19]. For Northern blot analyses $20 \mu \mathrm{g}$ RNA per slot were electrophoresed on $1.5 \%$ agarose gels containing $6.3 \%$ formaldehyde. The hybridization probes were for fos: pfos (M) 780 , pUC12 containing the 780-bp Pst I/Sst I fragment of exon $3 / 4$ of c-fos (mouse) [6]; for $\mathrm{H}-2$ : $\mathrm{pH}-2^{\mathrm{d}}-1$ [20]; for myc: the $1.0-\mathrm{kb}$ $\mathrm{Xba}$ ISst I fragment of the mouse c-myc gene [21] containing exon 2; for actin: the 270-bp Eco RI/Hind III fragment of rat $\beta$ actin clone pactin 72 [22].

\subsection{M13 construction}

For S1 mapping the 260-bp Eco RI/Pst I fragment of intron 1 /exon 2 of the mouse c-fos gene and the 165-bp Xba I/Pst I 
fragment of intron 1/exon 2 of the mouse c-myc gene were cloned into M13mp18. For the nuclear run-on analyses of cmyc probes a (540 bp Sma I/Bam HI), b (450 bp Bam HI/Sst I), c (750 bp Sst I/Bam HI), d (165 bp Xba I/Pst I), e (1500 bp Sst I/Hind III) and $\mathrm{f}$ (510 bp Pvu II/Hind III) were cloned into M13mp18 and M13mp19. For c-fos the probes were a (950 bp Sst I/Pvu II), b (600 bp Pvu II/Xho II), c (260 bp Eco RI/Pst I), $\mathrm{d}(780 \mathrm{bp}$ Pst I/Sst I) and e (810 bp Sst I/Tth III) cloned into M13mp18 and M13mp19. The H-2-specific probes were a 300bp Pst I fragment of $\mathrm{pH}-2^{\mathrm{d}}-1$ cloned in $\mathrm{M} 13 \mathrm{mp} 18$ and M13mp19. The ribosomal probes were the 320-bp Sal I/Sma I fragment of mouse ribosomal DNA cloned into M13mp8 and M13mp9 (a gift of I. Grummt, Institute for Biochemistry, Würzburg).

\subsection{Nuclear run-on assay}

Preparation of nuclei and elongation of transcription were performed as described elsewhere [23, 24]. Half $\mu \mathrm{g}$ of the indicated single-stranded M13 DNA probes was slot blotted in $20 \times \operatorname{SSC}(3 \mathrm{M} \mathrm{NaCl}, 0.3 \mathrm{M}$ sodium citrate) on Hybond $\mathrm{N}$ filters (Amersham International, Bucks, GB). The filters were prehybridized for $24 \mathrm{~h}$ at $42{ }^{\circ} \mathrm{C}$ in $50 \%$ formamid, $5 \times$ Denhardt's, $6 \times$ SSPE, $250 \mu \mathrm{g} / \mathrm{ml}$ carrier RNA, $0.5 \%$ sodium dodecyl sulfate. Hybridization was performed for 3 days in the same buffer containing $4 \times 10^{6} \mathrm{cpm}$ of labeled RNA in $10 \mathrm{ml}$.

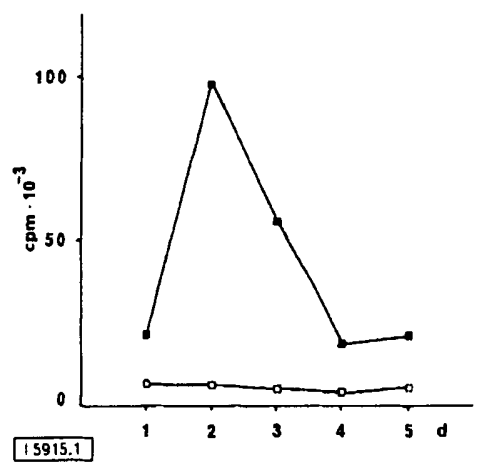

Figure 1. $\left[{ }^{3} \mathrm{H}\right]$ Thymidine incorporation. $\left[{ }^{3} \mathrm{H}\right]$ Thymidine incorporation of mouse splenic lymphocytes with (- and without ([- $\square$ ) Con A $(2.5 \mu \mathrm{g} / \mathrm{ml})$ in RPMI 1640 medium containing 5\% FCS. Two $\times 10^{4}$ lymphocytes were labeled for $16 \mathrm{~h}$ with $5 \mu \mathrm{Ci}\left[{ }^{3} \mathrm{H}\right]$ thy. midine $(2 \mathrm{Ci} / \mathrm{mmol})$

\subsection{S1 mapping}

For primer extension, $1.5 \mu \mathrm{g}$ ss M13 DNA was hybridized to the 15-bp sequencing primer (Pharmacia, Uppsala, Sweden) and the complementary strand was synthesized with $30 \mu \mathrm{Ci}$ $\alpha-{ }^{32} \mathrm{P}$-dATP by polymerase I large fragment. Hybridization and nuclease $\$ 1$ mapping were performed as described elsewhere $[25,26]$. Single-stranded nucleic acids were digested with $700 \mathrm{U} / \mathrm{ml}$ nuclease $\mathrm{S} 1$ (Pharmacia) at $30^{\circ} \mathrm{C}$. The hybrids were run on a $8 \%$ polyacrylamid gel containing $7 \mathrm{M}$ urea.

\section{Results}

\subsection{The kinetics of c-fos and c-myc mRNA expression}

The rates of $\left[{ }^{3} \mathrm{H}\right]$ thymidine incorporation by splenic mouse lymphocytes cultured in RPMI 1640 medium containing 5\% FCS in the presence and absence of Con $A$ are presented in Fig. 1. An increased incorporation of $\left[{ }^{3} \mathrm{H}\right]$ thymidine was only apparent in Con A-stimulated, proliferating lymphcoytes.

The relative amounts of $c$-fos and c-myc-specific mRNA in these cells were determined by Northern blot analyses. C-fosspecific mRNA increased drastically reaching its optimum already $1 \mathrm{~h}$ after preparation of the single cell suspension from mouse spleens and stimulation with Con A (Fig. 2A). However, exactly the same results were obtained with lymphocytes cultured in the absence of Con A (Fig. 2B) and even in the absence of FCS, i.e. in cells showing no proliferative activities (compare Fig. 1). Thus, the peculiar kinetics of c-fos gene expression were totally independent of whether or not the cells are growth activated. Addition of $\mathrm{CHI}$ could not prevent the down-regulation of c-fos mRNA. In contrast to c-fos, c-myc mRNA levels increased about 50-fold only in lymphocytes stimulated to proliferation with Con $A[1,14]$ (compare Fig. 7B). Nonproliferating lymphocytes expressed c-myc mRNA at a low level, about $10 \%$ of maximal expression $6 \mathrm{~h}$ after Con A stimulation (data not shown).

\subsection{Decay rates of c-fos and c-myc mRNA}

The decay rates of c-fos and c-myc mRNA were assessed in activated lymphocytes after blocking further transcription by actinomycin D (Act D) and preparation of total cellular RNA $5,15,30,60$ and $120 \mathrm{~min}$ thereafter. The densitometric evalu-

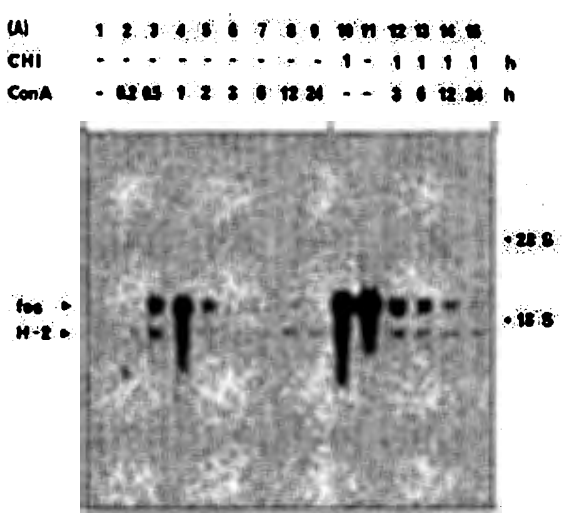

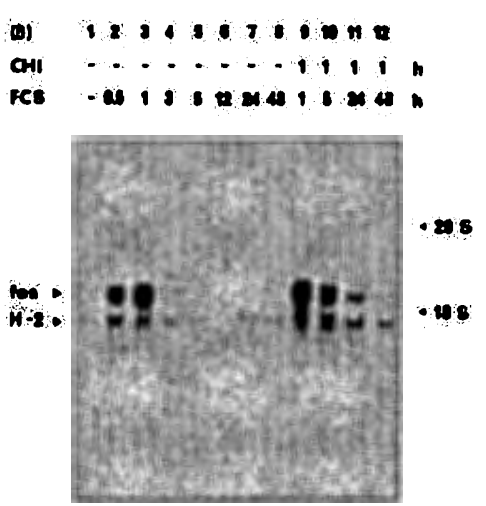

Figure 2. Northern blot of proliferating and non-proliferating lymphocytes. Lymphocytes were cultured for various times in RPMI 1640 medium containing $5 \% \mathrm{FCS}$ with (A) or without (B) $2.5 \mu \mathrm{g} / \mathrm{ml}$ Con A. CHI was given during the last $60 \mathrm{~min}$ of cultivation in a concentration of $10 \mu \mathrm{g} / \mathrm{ml}$. The Northern blots were hybridized to the nick-translated plasmid pfos (M) 780 containing the 780 -bp Pst I/Sst I fragment of exon 3 and 4 of c-fos (mouse) and plasmid $\mathrm{pH}-2^{\mathrm{d}}-1$ as a control of intact RNA. The RNA of (A), lane 10 was prepared from lymphocytes treated with $10 \mu \mathrm{g} / \mathrm{ml} \mathrm{CHI}$ for $1 \mathrm{~h}$ without FCS and Con A in RPMI 1640 at $37^{\circ} \mathrm{C}$. The RNA of (A), lane 11 was prepared from lymphocytes treated for $1 \mathrm{~h}$ with RPMI $5 \%$ FCS without Con A, the same RNA as in (B), lane 3 . 
ations of the corresponding Northern blots are shown in Fig. 3. At 30 min post stimulation the half-life of c-fos mRNA was approximately $14 \mathrm{~min}, 1 \mathrm{~h}$ post stimulation the half-life was $25 \mathrm{~min}$ and $2 \mathrm{~h}$ post stimulation it was $70 \mathrm{~min}$ (Fig. 3A).
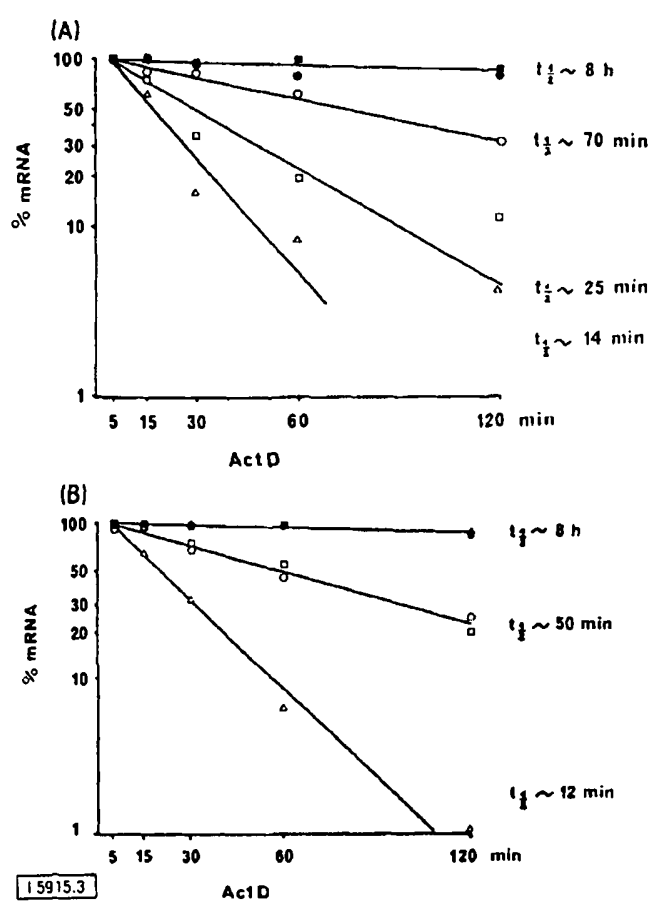

Figure 3. Half-lives of c-fos (A) and c-myc (B) mRNA. (A) Lymphocytes were cultured in RPMI $5 \%$ FCS with $2.5 \mu \mathrm{g} / \mathrm{ml}$ Con A. After $30 \mathrm{~min}(\Delta-\Delta), 1 \mathrm{~h}(\mathrm{\square}-\square)$ and $2 \mathrm{~h}(\mathrm{O}-\mathrm{O})$ transcription was blocked by addition of $5 \mathrm{\mu g} / \mathrm{ml}$ Act $\mathrm{D}$ and cells were harvested 5,15 , 30,60 and $120 \mathrm{~min}$ later. $\mathrm{CHI}(20 \mu \mathrm{g} / \mathrm{ml})$ was added $30 \mathrm{~min}$ before addition of Act $D$ at $1 \mathrm{~h}(\longrightarrow)$ and $2 \mathrm{~h}(-)$ of culture. Northern blots of corresponding RNA were hybridized with a c-fos-specific probe and scanned by densitometry. The highest absorption at $5 \mathrm{~min}$ after addition of Act $D$ each was set to $100 \%$ of the mRNA survival curves. (B) For determination of the half-lives of c-myc mRNA, lymphocytes were cultured in RPMI $5 \%$ FCS with $2.5 \mu \mathrm{g} / \mathrm{ml}$ Con A. After $2 \mathrm{~h}(\mathrm{O}-\mathrm{O}), 6 \mathrm{~h}([-\square)$ and $48 \mathrm{~h}(\Delta-\Delta)$ transcription was blocked by addition of $5 \mu \mathrm{g} / \mathrm{ml}$ Act D. CHI $(20 \mu \mathrm{g} / \mathrm{ml})$ was added 30 min before addition of Act D at $6 \mathrm{~h}(\square-D)$ and $48 \mathrm{~h}(\triangle-\Delta)$ of culture. Northern blots of corresponding RNA were hybridized with a c-myc-specific probe and scanned by densitometry.

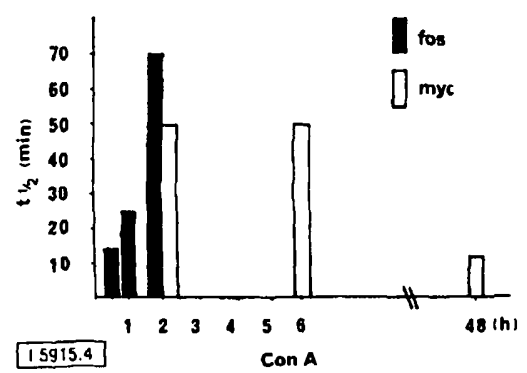

Figure 4. Variation of the natural half-lives of $c$-fos and c-myc mRNA. The natural half-lives of $c$-fos mRNA were determined to be $14 \mathrm{~min}$ (at $30 \mathrm{~min}$ of culture), $25 \mathrm{~min}$ (at $1 \mathrm{~h}$ of culture) and $70 \mathrm{~min}$ (at $2 \mathrm{~h}$ of culture). The natural half-lives of c-myc mRNA were $50 \mathrm{~min}$ (at 2 and $6 \mathrm{~h}$ post stimulation) and decreased to $12 \mathrm{~min}$ (at $48 \mathrm{~h}$ post stimulation).
At 2 and $6 \mathrm{~h}$ post stimulation the half-lives of c-myc mRNA were determined to be $50 \mathrm{~min}$ and at $48 \mathrm{~h}$ post stimulation the half-live of c-myc mRNA was reduced to about $12 \mathrm{~min}$ (Fig. 3B). CHI stabilized both c-fos and c-myc mRNA to halflives of about $8 \mathrm{~h}$, independently of the state of activation of the cells. The changes of the natural half-lives of $c$-fos and c-myc mRNA are summarized in Fig. 4.

The short half-lives of the mature mRNA and the changes of their decay rates were specific for c-fos and c-myc mRNA. Control hybridization of the same Northern blots with $\mathrm{H}$-2- or actin-specific probes showed no variation in the decay rates of the mRNA of these genes.

\subsection{Transcription rates of c-myc and c-fos RNA}

Nuclear run-on analyses were then performed to determine the transcription rates of the c-myc, c-fos, H-2 and ribosomal genes after stimulation of the lymphocytes. With this technique RNA polymerase II density or elongation rate without initiation was investigated. The probes used in the run-on experiment were single-stranded M13 DNAs as indicated in Fig. 5B, specific for parts of the c-myc and c-fos genes. Probes specific for both orientations of RNA were used, $(+)$ probes detecting mRNA sense and $(-)$ probes detecting anti-sense RNA transcripts. The $\mathrm{H}-2$ and ribosomal probes were used for control and standardization purposes.

Nonactivated lymphocytes $(10 \mathrm{~min}$ after preparation of the single cell suspension) (Fig. 5A, lane 1) showed significant transcription of the exon 1 and exon $1 /$ intron 1 boundary of $c-$ myc (probes $b$ and $c$ ), but the elongation rates of the second and third exon of $c$-myc (probes $d-f$ ) were low. The first exon of the c-fos gene (probe $b$ ) also appeared to be transcribed already at $0 \mathrm{~h}$ (Fig. 5A, lane 1) to the same extent as after $30 \mathrm{~min}$ of Con A stimulation (Fig. 5A, lane 2). The elongation rates of c-fos to exons 3 and 4 were slower at $0 \mathrm{~h}$ than $30 \mathrm{~min}$ later (probes d, e). At subsequent times investigated transcription of c-fos was strongly down-regulated (Fig. 5A, lanes 4 to 7), whereas the elongation rates of exon 2 and 3 of c-myc (probes $\mathrm{d}-\mathrm{f}$ ) increased about 5 -fold at $6 \mathrm{~h}$ post activation (Fig. 5A, lane 4) and were down-regulated thereafter. CHI had some effect on the elongation rate of c-fos at $30 \mathrm{~min}$ (Fig. 5A, lane 3), but no effect could be detected at later times. Thus, CHI per se does not lead to c-fos for c-myc transcription.

The (-) probe c of c-myc, specific for the exon 1/intron 1 boundary of the c-myc gene, detected transcription of significant levels of complementary RNA to c-myc mRNA in nonactivated lymphocytes (Fig. 5A, lane 1). Following activation of the lymphocytes, the signal for anti-sense RNA decreased to background levels. No signal for anti-sense RNA could be detected with the $(-)$ c-fos-specific probes. As a control for possible cross-hybridization the filter of Fig. 5A, lane 1 was washed and rehybridized with a radioactively labeled $(+)$ SP6 transcript of the c-myc probe $c$, but no signal for the corresponding (-) probe could be seen.

\subsection{S1 protection analyses}

This technique enables steady state levels of mature mRNA and corresponding precursor mRNA to be simultaneously 

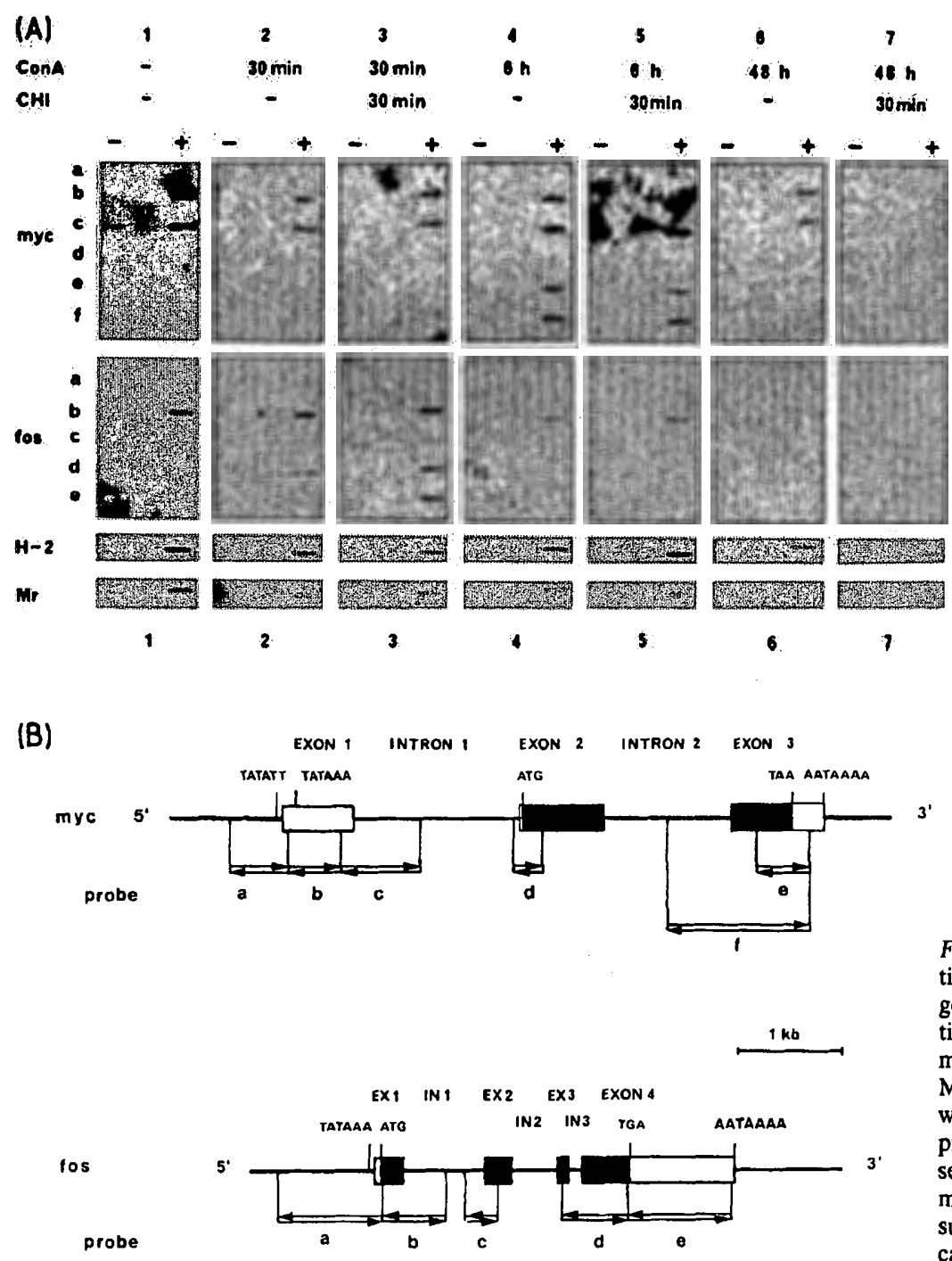

Figure 5. Nuclear run-on analyses. (A) The elongation rates of c-myc, c-fos $\mathrm{H}-2$ and ribosomal (Mr) genes in lymphocytes were determined after various times of Con A stimulation without and with $20 \mu \mathrm{g} /$ $\mathrm{ml} \mathrm{CHI}$ as indicated lane 1-7). Of single-stranded M13 DNA specific for both orientations $(0.5 \mu \mathrm{g})$ were slot blotted on Hybond $\mathrm{N}$ filter, $(+)$ indicating probes detecting mRNA and $(-)$ detecting antisense RNA. (B) The probes a-f from the mouse cmyc gene and a-e of the mouse c-fos gene were subcloned into M13mp18 and M13mp19 as indicated and slot blotted on Hybond $\mathrm{N}$ filter used in (A).

assessed. The results obtained with a c-fos intron 1/exon 2 specific M13 probe are shown in Fig. 6. Regarding the signal for mature mRNA consisting of a protected sequence of 80 nucleotides of exon 2, the previous results obtained with Northern blot analysis were confirmed. The strongest signal was observed $1 \mathrm{~h}$ post stimulation and disappeared thereafter. The c-fos-specific precursor mRNA (signal at 260 nucleotides) was demonstrable already in unstimulated cells (at $0 \mathrm{~h}$ ) until $1 \mathrm{~h}$ post stimulation (Fig. 6B, lanes 5-8). After that time precursor mRNA was no longer demonstrable by this technique. As a control for the amount of RNA used in the assay, a probe for ribosomal RNA was hybridized simultaneously to each RNA sample giving the signal at 155 nucleotides. In the case of c-myc the levels of mature mRNA (signal at 132 nucleotides) were maximal at $6 \mathrm{~h}$ post stimulation of lymphocytes with Con A (Fig. 7B). Within the first hours post stimulation, precursor mRNA levels (signal at 165 nucleotides) increased parallel with mature mRNA levels and decreased thereafter. CHI had no effect on precursor mRNA levels of c-myc (data not shown). These results confirmed the data of the nuclear run-on analyses of c-fos and c-myc transcription rates and determination of the decay rates of the corresponding mRNA.

\section{Discussion}

The exact and sensitive regulation of the expression of genes required for proliferation and differentiation is a prerequisite for lymphocytes in a normal, functioning immune system. As shown by Northern blot analyses and $S 1$ mapping $[1,14]$ the $c$ myc gene expression is stimulated transiently about 50 -fold during the $\mathrm{G}_{0}$ to $\mathrm{S}$-phase transition of lymphocytes. Nonstimulated lymphocytes, kept in medium with $5 \%$ FCS, did not show high levels of $c-m y c$ mRNA. In contrast to $c-m y c, c-f o s-$ specific mRNA is expressed with maximal levels after $1 \mathrm{~h}$ also in nonproliferating lymphocytes and in the presence or absence of FCS in the culture media. Thus, expression of the cfos gene in these cells is totally independent of whether or not the cells are stimulated for subsequent growth. According to these findings the c-myc, but not the c-fos gene, would qualify 


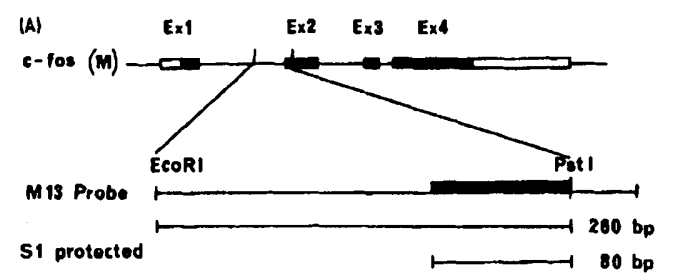

(8)

0.0205121612 h Conia

$1234507+010112$

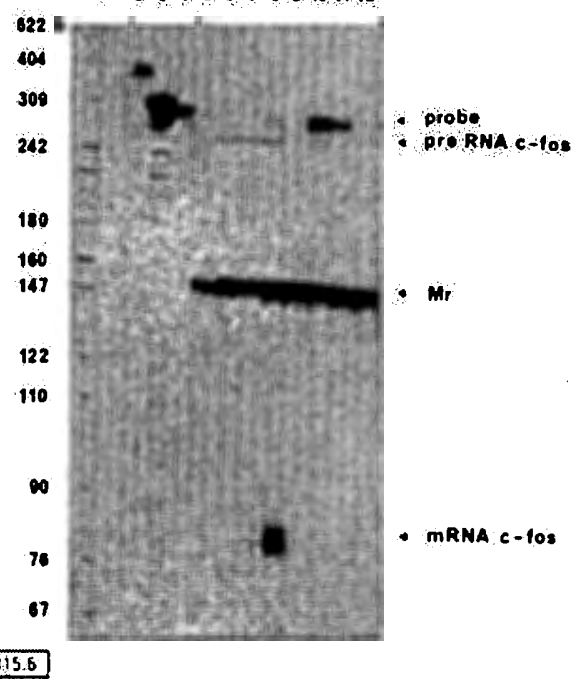

Figure 6. Nuclease S1 mapping. (A) To show the precursor mRNA to mRNA ratio of c-fos the 260 -bp Eco RI/Pst I fragment of the first intron and the second exon of c-fos (mouse) was cloned into M13mp18. The labeled probe has a size of 310 nucleotides (nt, multiple cloning site). The nuclease $S 1$ protected precursor mRNA gives a signal at $260 \mathrm{nt}$, the mRNA at $80 \mathrm{nt}$. (B) Total cellular RNA of stimulated lymphocytes was hybridized to the M13 probe and singlestranded nucleic acids were digested by nuclease S1 (see Sect. 2.5). Lane 1: end-labeled marker pBR322 digested with Hpa II. Lane 2: the probe for mouse ribosomal RNA in M13mp9. The ribosomal RNA gives a signal at $155 \mathrm{nt}(\mathrm{Mr})$ and was used as a control of the amount of RNA used in the experiment. Lanes 3 and 4 show the M13 probe for c-fos alone and S1-treated, respectively. Lanes 5-12 contain RNA of the Con A-stimulated lymphocytes as indicated.

for a possible association with growth regulation of lymphocytes.

Both the levels of c-myc and c-fos-specific mRNA are decreasing after having reached maximum values at $6-12 \mathrm{~h}$ and $1 \mathrm{~h}$, respectively. One mechanism which can strongly influence steady state levels of mRNA is post-transcriptional regulation, in particular the specific degradation of mature mRNA. This has been shown to be the case for both c-myc and c-fos mRNAs $[2,10,11,15,16,27,28]$. By determining degradation rates of c-myc mRNA in Con A-stimulated cells, we found that it increased about 5 -fold from $6 \mathrm{~h}$ to $48 \mathrm{~h}$ post stimulation (Fig. 4). The half-lives were determined to be $50 \mathrm{~min}$ at 2 and $6 \mathrm{~h}$ and $12 \mathrm{~min}$ at $48 \mathrm{~h}$ post stimulation. In contrast, the halflives of c-fos mRNAs were $14 \mathrm{~min}$ at $30 \mathrm{~min}$ post stimulation and increased to $70 \mathrm{~min}$ at $2 \mathrm{~h}$ post stimulation. This initial and extreme instability of the c-fos mRNA could explain the lack of demonstrable levels prior to $30 \mathrm{~min}$ of culture. Our
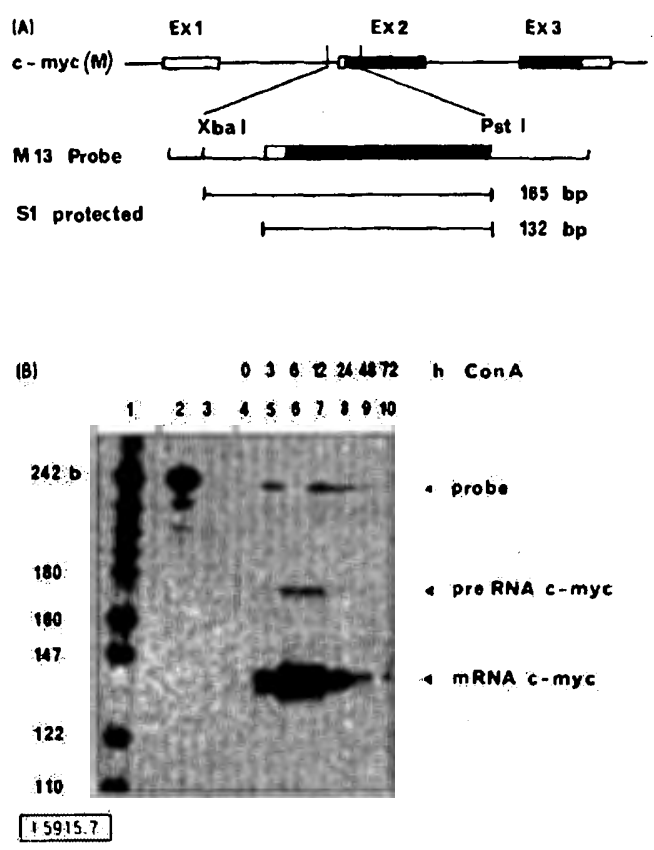

Figure 7. Nuclease S1 mapping. (A) The 165 bp Xba I/Pst I fragment of intron 1 and exon 2 of c-myc (mouse) was cloned into M13mp18. The labeled probe has a size of $240 \mathrm{nt}$. The size of nuclease S1 protected c-myc precursor mRNA is $165 \mathrm{nt}$, the size of protected mRNA $132 \mathrm{nt}$. (B) Total cellular RNA of stimulated lymphocytes was hybridized to the M13 probe and single-stranded nucleic acids were digested by nuclease S1 (see Sect. 2.5). Lane 1: end-labeled marker pBR322 digested with Hpa II. Lanes 2 and 3: the c-myc-specific M13 probe alone and $\mathrm{S} 1$ treated, respectively. Lanes 4-10 contain RNAs of the Con A-stimulated lymphocytes as indicated.

data show that the degradation rates of different mRNA species in lymphocytes are regulated specifically and independent from one another. The strongly stabilizing effect of $\mathrm{CHI}$ on c-fos and c-myc mRNA suggests that translation may be necessary for mRNA degradation $[29,31,32]$.

The other important mechanism that can influence mRNA steady state levels is regulation of gene transcription per se. Nuclear run-on experiments with c-fos-specific probes showed transcription of exon 1 already 10 min after the single cell suspension had been prepared from mouse spleens $(0 \mathrm{~h}$ in Fig. 5A) and without any additional manipulation or activation of the lymphcoytes. Exons 3 and 4 were transcribed to a lesser extent at that time, but their transcription increased after 30 min of culture. This could suggest a block to elongation within the c-fos gene, which is released after stimulation or, alternatively, the high polymerase II density in exon 1 of cfos may reflect the beginning transcription of this gene. The data are in keeping with c-fos-specific precursor mRNA being demonstrable even in nonactivated cells. It remains to be seen whether or not the c-fos gene is already transcribed in spleen cells in vivo. Transcription even of exon 1 of $c$-fos is shut-off after $48 \mathrm{~h}$ in culture. Transcription of the entire c-myc gene to precursor mRNA is increased about 5-fold in lymphocytes treated for $6 \mathrm{~h}$ with Con $A$ as compared to unstimulated cells (Fig. 5A, lane 4). However, the first exon of c-myc seems to be transcribed also in nonactivated cells (Fig. 5A, lane 1). This would suggest a block to elongation at the exon 1 /intron 1 boundary which prevents complete c-myc gene transcription 
in nonactivated lymphocytes. Similar results were obtained with HL-60 and 54c12 (3T3) cells [24, 30, 33, 34] which, however, possess amplified c-myc genes. Nuclear run-on analyses also showed a significant transcription of RNA complementary to c-myc mRNA, again only in nonactivated cells (Fig. 5A, lane 1, probe c). In contrast to the reports by Bentley and Groudine [24] and Nepveu and Marcu [34], we could detect anti-sense RNA transcription only with probe $c$ which is specific for the exon $1 /$ intron 1 boundary of the c-myc gene. Since both abortive transcription of sense and the transcription of anti-sense RNA take place in this part of the gene, one may speculate that the anti-sense transcription could play a role in the regulation of mRNA elongation. Indeed, as transcription of the c-myc gene proceeds further downstream after Con A stimulation, the signal for anti-sense RNA disappears.

In conclusion, the expression of c-fos and c-myc genes in cultured normal mouse lymphocytes is finely tuned by an interplay of transcriptional and post-transcriptional control mechanisms which change in predominance at the various stages between $G_{0}$ and S-phase. Of course, it still remains a matter of conjecture whether or not these phenomena represent an important mechanism of lymphocyte activation. For reasons discussed above, $c$-fos gene expression appears to be less important in that respect. Transgenic mice in which c-fos gene expression is deregulated show abnormal bone formation [35]. Regarding the c-myc gene, however, it is noteworthy that most of the reports dealing with its expression are based on cells of the lymphoid tissue. Deregulated c-myc expression interferes with proliferation and maturation of lymphoid cells in transgenic mice $[36,37]$. Thus, the fine regulation of $c$-myc expression in normal lymphocytes as described here seems indeed to be instrumental for their normal function.

We thank Ms. I. Grummt for providing us with the ribosomal DNA M13 clones, Mr. R. Knauer for preparation of two c-fos-specific M13 clones, Ms. F. Siebelt for two c-myc-specific M13 clones and Ms. C. Stoppe for her patience and skills during the preparation of this manuscript.

Received December 22, 1986; in revised form February 19, 1987.

\section{References}

1 Kelly, K., Cochran, B. H., Stiles, C. D. and Leder, P., Cell 1983. 35: 603 .

2 Thompson, C. B., Challoner, P. B., Neiman, P. E. and Groudine, M., Nature 1985. 314: 363.

3 Greeberg, M. E. and Ziff, E. B., Nature 1984. 311: 433.

4 Müller, R. and Wagner, E. F., Nature 1984. 311: 438.
5 Kruijer, W., Cooper, J. A., Hunter, T., Verma, I. M., Nature 1984. 312: 711.

6 Müller, R., Bravo, R., Burckhardt, J., Nature 1984. 312: 716.

7 Lau, L. F. and Nathans, D., EMBO J. 1985. 4: 3145.

8 Gonda, T. J. and Metcalf, D., Nature 1984. 310: 249.

9 Mitchell, R. L., Zokas, L., Schreiber, R. D., Verma, I. M., Cell 1986. 45: 497.

10 Mitchell, R. L., Henning-Chubb, C., Huberman, E., Verma, I., Cell 1986. 42: 497.

11 Treisman, R., Cell 1985. 42: 889.

12 Reed, J. C., Sabath, D. E., Hoover, R. G. and Prystowsky, M. B., Mol. Cell. Biol. 1985. S: 3361.

13 Kaczmarek, L., Calabretta, B., Baserga, R., Proc. Natl. Acad. Sci. USA 1985. 82: 5375.

14 Schneider-Schaulies, J., Hünig, T., Schimpl, A., Wecker, E., Eur. J. Immunol. 1986. 16: 312.

15 Dani, C., Blanchard, J. M., Piechaczyk, M., El Sabouty, S., Marty, L., Jeanteur, P., Proc. Natl. Acad. Sci. USA 1984. 81: 7046.

16 Knight, E., Anton,E. D., Fahey, D., Friedland, B. K. and Jonak, G. J., Proc. Natl. Acad. Sci. USA 1985. 82: 1151.

17 Dony, C., Kessel, M., Gruss, P., Nature 1985. 317: 636.

18 Piechaczyk, M., Yang, J.-Q., Blanchard, J.-M., Jeanteur. P., Marcu, K. B., Cell 1985. 42: 589.

19 Chirgwin, J. M., Przybyla, A. E., MacDonald, R. J.and Rutter, W. J., Biochemistry 1979. 18: 5294.

20 Bregégère, F., Abastado, J. P., Krist, S., Rask, L., Lalanne, J. L., Garoff, H., Cami, B., Wiman, K., Larhammer, D., Peterson, P. A., Gachelin, G., Kourilski, P. and Dobberstein, B., Nature 1981. 292: 78.

21 Bernard, O., Cory, S., Gerondakis, S., Webb, E. and Adams, J. M., EMBO J. 1983. 12: 2375.

22 Nudel, U., Zakut, R., Shani, M., Neumann, S., Levy, Z. and Yaffe, D., Nucleic Acids Res. 1983. 11: 1759.

23 Carneiro, M. and Schibler, U., J. Mol. Biol. 1984. 178: 869.

24 Bentley, D. L. and Groudine, M., Nature 1986. 321: 702.

25 Favaloro, F. G., Treisman, R. and Kamen, R., Methods Enzymol. 1980. 65: 718.

26 Stanton, W. L., Watt, R., Marcu, K. B., Nature 1983. 303: 401.

27 Einat, M., Resnitzky, D., Kimchi, A., Nature 1985. 313: 597.

28 Thompson, C. B., Challoner, P. B., Neimann, P. E. and Groudine, M., Nature 1986. 319: 374.

29 Linial, M., Gunderson, N. and Groudine, M., Science 1985. 230: 1126.

30 Eick, P., Piechaczyk, M., Henglein, B., Blanchard, J. M., Traub, B., Kofler, E., Wiest, S., Lenoir, G. M. and Bornkamm, G. W., EMBO J. 1985. 4: 3717.

31 Saito, H., Hayday, A., Wiman, K., Haward, W. and Tonegawa, S., Proc. Natl. Acad. Sci. USA 1983. 80: 7476.

32 Shaw, G. and Kamen, R., Cell 1986. 46: 659.

33 Bentley, D. L. and Groudine, M., Mol. Cell. Biol. 1986. 6: 3481.

34 Nepveu, A. and Marcu, K. B., EMBO J. 1986. 5: 2859.

35 Rüther, U., Garber, C., Kouritowski, D., Müller, R. and Wagner, E., Nature 1987. 325: 412.

36 Langdon, W.Y., Harris, A.W., Cory, S. and Adams, J. M., Cell 1986. 47: 11.

37 Leder, A., Pattengale, P. K., Kuo, A., Timothy, A. S. and Leder, P., Cell 1986. 45: 485. 